\title{
Aplikasi Model Pembelajaran Inquiry Sebagai Upaya untuk Meningkatkan Prestasi Belajar Matematika
}

\section{Ketut Suhendrayani*}

SMP Negeri 3 Sawan, Buleleng, Indonesia

\section{A R T I C L E I N F O \\ Article history: \\ Received 17 May 2018 \\ Received in revised form 27 June 2018 \\ Accepted 10 July 2018 \\ Available online 26 \\ August 2018}

\section{Kata Kunci:}

Model Pembelajaran;

Inkuiri; Prestasi Belajar;

Matematika

Keywords:

Learning Model;

Inquiry; Learning

Achievement;

Mathematics

\begin{abstract}
A B S T R A K
Proses pembelajaran di kelas yang membuat prestasi belajar siswa rendah merupakan dasar pembuatan penelitian tindakan kelas ini. Penelitian ini dilakukan di kelas VIII A5 di SMP Negeri 3 Sawan pada semester Genap tahun pelajaran 2017/2018. Data hasil penelitian dikumpulkan menggunakan tes dan dianalisis menggunakan analisis deskriptif. Setelah semua proses dilaksanakan yang dimulai dengan perencanaan, dilanjutkan dengan pelaksanaan diteruskan dengan observasi/pengumpulan data dan diakhiri dengan refleksi yaitu melakukan analisis, ternyata data yang diperoleh cukup menggembirakan. Nilai awal yang rata-rata awalnya masih rendah yaitu 69,23 dengan ketuntasan belajar baru mencapai 7,69\% dan pada siklus I sudah meningkat menjadi 79,04 dengan ketuntasan belajar 65,38\% dan meningkat signifikan pada Siklus II menjadi 83,65 dengan ketuntasan belajar 92,31\%. Data tersebut menunjukkan keberhasilan penelitian tindakan kelas ini sehingga peneliti berkesimpulan bahwa model pembelajaran Inquiri mampu meningkatkan prestasi belajar Matematika siswa kelas VIIIA5 di SMP Negeri 3 Sawan.
\end{abstract}

\section{A B S T R A C T}

The learning process in the classroom that makes low student achievement is the basis for making this classroom action research. This research was carried out in class VIII A5 at SMP Negeri 3 Sawan in even semester of 2017/2018 school year. Research data were collected using tests and analyzed using descriptive analysis. After all the processes were carried out which began with planning, continued with the implementation continued with observation/data collection and ended with a reflection that was doing analysis, it turned out that the data obtained was quite encouraging. The initial value which was initially low was 69.23 with learning completeness only at $7.69 \%$, and in the first cycle, it had increased to 79.04 with 65.38\% learning completeness and significantly increased in Cycle II to $83.6592 .31 \%$ learning completeness. This data shows the success of this class action research so that the researcher concludes that the Inquiry learning model can improve the mathematics learning achievement of VIIIA5 students in SMP Negeri 3 Sawan.

\footnotetext{
* Corresponding author.

E-mail addresses: suhendrayani@gmail.com
} 


\section{Pendahuluan}

SMP Kurikulum Tingkat Satuan Pendidikan di SMP Negeri 3 Sawan semester genap tahun pejaran 2017/2018, khususnya pada mata pelajaran Ilmu Matematika, ketuntasan belajar siswa ditentukan berdasarkan Kriteria Ketuntasan Minimal (KKM) 76,00. Dalam upaya pencapaian kriteria ketuntasan minimal tersebut semestinya kegiatan pembelajaran yang dirancang dan diterapkan mampu memberdayakan siswa untuk belajar sehingga terjadi pengkonstruksian secara optimal. Tetapi dalam pelaksanaan pembelajaran di kelas, antara Rencana Pelaksanaan Pembelajaran (RPP) yang disusun dengan kegiatan pembelajaran belum sesuai. Guru masih mendominasi kegiatan pembelajaran dengan ceramah untuk semua kompetensi dan memberikan tugas terstruktur. Selama kegiatan pembelajaran prasiklus, semua informasi atau data terkait materi yang dibelajarkan disampaikan oleh guru dan siswa diwajibkan untuk memperhatikan dan mencatat penjelasan guru. Pada akhir kegiatan pembelajaran semua siswa diberikan individu (tugas terstruktur) sesuai materi yang sudah dibelajarkan.

Tugas individu yang diberikan ternyata tidak semua siswa mampu mengerjakan dengan baik. Hasil wawancara dengan beberapa siswa mengatakan bahwa mereka belum memahami tugas yang diberikan sehingga tidak mengerjakannya. Pada akhir pembelajaran prasiklus dilakukan penilaian dengan memberikan tes hasil belajar kepada semua siswa dan dilakukan analisis. Hasil analisis belajar Matematika siswa kelas VIII A5 pada standar kompetensi "Menentukan unsur,bagian lingkaran serta ukurannya" sebagai berikut. Kondisi siswa kelas VIII A5 semester genap tahun pelajaran 2017/2018 untuk mata pelajaran Matematika baru mencapai nilai rata-rata 69,23 dengan ketuntasan belajar 7,69\%. Nilai rata-rata ini belum sesuai dengan nilai kriteria ketuntasan minimal (KKM) mata pelajaran Matematika yang harus dipenuhi yaitu 76.

Kenyataan di atas ternyata bersumber dari kegiatan belajar mengajar pendidikan Matematika ini kurang menarik bagi siswa karena dianggap sebagai pelajaran yang membosankan yang memerlukan latihan-latihan banyak yang monoton, sehingga membuat siswa merasa jenuh.

Untuk meningkatkan prestasi belajar Matematika, solusi dari kegagalan tersebut adalah peneliti berusaha untuk menemukan dan memilih metode pengajaran yang setepat-tepatnya yang dipandang lebih efektif dari pada metode-metode lainnya, sehingga kecakapan dan pengetahuan yang diberikan oleh guru benar-benar menjadi milik murid. Salah satu metode yang peneliti gunakan adalah model pembelajaran Inquiry.

Meningkatkan keterlibatan siswa secara maksimal dengan memberi motivasi-motivasi, inovasi perbaikan pelaksanaan adalah upaya yang dilakukan dalam pemecahan masalah penelitian ini dengan cara melaksanakan langkah-langkah model pembelajaran Inquiry dalam proses belajar mengajar karena model pembelajaran ini mempunyai langkah yang bisa diterapkan guru dalam upaya meningkatkan mutu pembelajaran. Model ini mempunyai langkah-langkah yang mendorong keaktifan siswa dalam belajar dengan cara memberikan kesempatan bagi siswa untuk lebih banyak mengamati objek atau materi pelajaran, menemukan sendiri hal-hal yang perlu, baik menyangkut materi, meneliti, mengintrogasi, memeriksa materi, menyusun pertanyaan sendiri dan berusaha mencari jawaban itu dengan bantuan guru sehingga siswa-siswa akan dapat mengalami sendiri.

Seluruh aktivitas yang dilakukan siswa dalam pembelajaran diarahkan untuk mencari dan menemukan sendiri dari sesuatu yang dipertanyakan, sehingga diharapkan dapat menumbuhkan sikap percaya diri. Artinya dalam pendekatan inkuiri menempatkan guru bukan sebagai sumber belajar, akan tetapi sebagai fasilitator dan motivator belajar siswa. Tujuan dari penggunaan model pembelajaran pembelajaran inkuiri adalah mengembangkan kemampuan intelektual sebagai bagian dari proses mental, akibatnya dalam pembelajaran inkuiri siswa tidak hanya dituntut agar menguasai pelajaran, akan tetapi bagaimana mereka dapat menggunakan potensi yang dimilikinya untuk mencari solusi dari permasalahan yang dihadapi. Misalnya, saja tentang menentukan unsur-unsur dan bagian lingkaran, dapat dipecahkan dengan Menentukan pendekatan nilai perbandingan keliling lingkaran dengan diameter melalui percobaan

Berdasar uraian singkat ini jelas bahwa model pembelajaran Inquiry menuntut kemampuan siswa untuk giat mempelajari apa yang disampaikan guru, mampu menampilkan dirinya sebagai pemikir di depan siswa-siswa yang lain. Dipihak lain, untuk dapat menyelesaikan tuntutan tersebut, inovasi yang dilakukan guru akan sangat menentukan. Inovasi tersebut berupa tuntunan-tuntunan, motivasi-motivasi, interpretasi serta kemampuan belajar tanpa hafalan. Oleh karenanya langkah-langkah ini diharapkan akan dapat digunakan sebagai cara pemecahan masalah.

Mulyasa, 2003 (dalam Maksum, 2006) menulis bahwa Inquiry pada dasarnya adalah cara menyadari apa yang telah dialami, karena itu Inquiry menuntut peserta didik berpikir. Model ini menempatkan peserta didik pada situasi yang melibatkan mereka dalam kegiatan intelektual, menuntut peserta didik memproses pengalaman belajar menjadi sesuatu yang bermakna dalam kehidupan nyata. 
Dengan demikian, melalui model ini peserta didik dibiasakan untuk produktif, analitis dan kritis. Selanjutnya Jone 1979 (dalam Maksum, 2006) menyatakan pandangannya bahwa model Inquiry ialah suatu model pembelajaran yang dirancang dengan suatu sistem kegiatan belajar mengajar yakni menyangkut metode, teknik dan strategi pembelajaran yang memungkinkan para peserta didik mendapatkan jawaban sendiri secara optimal.

Bruner (dalam Putrayasa, 2005) menyatakan bahwa penggunaan model pembelajaran Inquiri memberikan beberapa keunggulan: (1) model pembelajaran inquiri meningkatkan potensi intelektual siswa, (2) siswa yang telah berhasil menemukan sendiri sehingga dapat memecahkan masalah yang ada akan meningkatkan kepuasan intelektualnya yang justru datang dari dalam diri siswa, (3) siswa dapat belajar bagaimana melakukan penemuan, yang hanya melalui proses melakukan penemuan itu sendiri, (4) belajar melalui inquiri dapat menunjang proses ingatan atau konsep yang telah dipahami siswa lebih lama dapat diingat, (5) belajar melalui inquiri, siswa dapat memahami konsep-konsep dan ide-idenya dengan baik, (6) pengajaran menjadi lebih berpusat pada siswa, (7) proses pembelajaran inkuiri dapat membentuk dan mengembangkan konsep diri, (8) melalui pembelajaran inkuiri dimungkinkan tingkat harapan bertambah, (9) model pembelajaran inquiri dapat mengembangkan bakat akademik, (10) model pembelajaran inquiri dapat menghindarkan siswa dari belajar dengan hafalan, dan (11) model pembelajaran inkuiri dapat memberikan waktu kepada siswa untuk mengasimilasi dan mengakomodasi informasi.

Dari semua penjelasan di atas sudah dapat ditarik suatu kesimpulan bahwa model Inquiri menuntut kemampuan siswa untuk menemukan sendiri sesuai arti Inquiry dari bahasa aslinya Inquiry yang berarti meneliti, menginterogasi, memeriksa materi yang telah diteliti, telah dimengerti, telah diperiksa merupakan sesuatu yang dialami sendiri oleh siswa yang akan dijadikan pusat perhatian untuk memikirkan hal-hal yang terkait dengan materi tersebut yang disebut kegiatan intelektual. Apa yang telah diteliti, diamati, diperiksa dan diinterogasi akan diproses dalam alam pikiran mereka dan akan menjasi sesuatu yang bermakna dalam kehidupan mereka kelak. Dalam upaya mengerti materi yang diamati dan diteliti mereka dibiasakan untuk produktif, mampu membuat analisis serta membiasakan mereka berpikir kritis. Pembelajaran dengan model ini erat kaitannya dengan apa yang ditulis guru adalam Rencana Pelaksanaan Pembelajaran (RPP) guru karena dalam RPP tersebut tertulis hal-hal seperti metode, strategi dan teknik agar para siswa bisa mendapat jawabannya sendiri secara optimal.

Pembelajaran berbasis iquiry adalah strategi mengajar yang mengkombinasikan rasa ingin tahu siswa dan metode ilmiah. Penggunaan strategi ini untuk meningkatkan pengembangan keterampilan berpikir kritis melalui kegiatan belajar seperti pada bidang sains. Penerapan strategi pembelajaran Inquiry ini merupakan upaya untuk membangkitkan rasa ingin tahu siswa. Dorongan itu berkembang melalui proses merumuskan pertanyaan, merumuskan masalah, mengamati, dan menerapkan informasi baru dalam meningkatkan pemahaman mengenai sesuatu masalah. Rasa ingin tahu itu terus ditumbuhkan untuk meningkatkan semangat bereksplorasi sehingga siswa belajar secara aktif dan mampu meningkatkan prestasi belajar. Surya (2004) mengemukakan prestasi belajar adalah seluruh kecakapan hasil yang dicapai (achivement) yang diperoleh melalui proses belajar berdasarkan test belajar. Aplikasi pembelajaran inquiry merupakan upaya untuk meningkatkan prestasi belajar matematika.

\section{Metode}

Gambar 1.

Desain penelitian yang digunakan adalah desain penelitian tindakan kelas seperti terlihat pada 


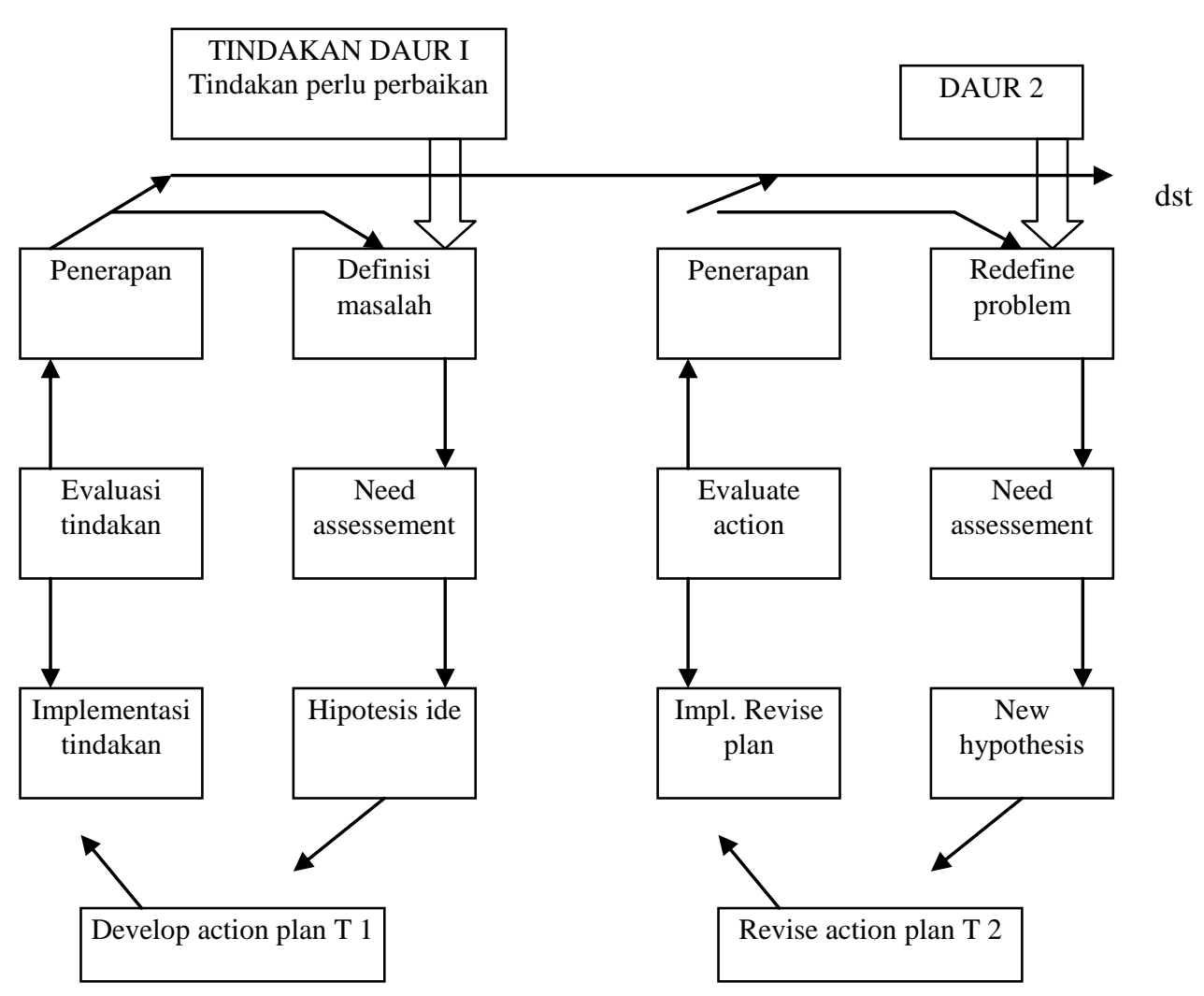

Gambar 1. Alur Penelitian Tindakan Model Mc. Kernan

(dalam Sukidin, Basrowi, Suranto, 2002)

Langkah-langkah yang mengacu pada Gambar 1 secara prosedural yang dilakukan adalah sebagai berikut. Tindakan daur I dilakukan definisi masalah dilanjutkan dengan pelaksanaan di lapangan, dirumuskan hipotesisnya, dikembangkan hipotesis tersebut, diimplementasikan, dievauasi dari hasil yang didapat dan evaluasi diterapkan. Langkah-langkah pada daur II atau siklus II sama dengan yang di siklus I yaitu dimulai dengan adanya suatu permasalahan yang baru, didefinisikan masalahnya, dibuat hipotesisnya direvisi, selanjutnya dialkukan implementasi di lapangan, dievaluasi, kemudian hasil yang didapat merupakan penerapan baru apabila masih adalah masalah.

Adapun subjek dalam penelitian ini adalah siswa kelas VIII A5 SMP Negeri 3 Sawan semester genap tahun pelajaran 2017/2018 dengan jumlah total 26 siswa. Dalam penelitian ini objek penelitiannya adalah peningkatan prestasi belajar Matematika siswa kelas VIII A5 semester genap SMP Negeri 3 Sawan. Pelaksanaan penelitian ini dijadwalkan dari bulan Januari sampai bulan April 2018.

Data yang diperoleh dalam penelitian ini dikumpulkan melalui test. Adapun analisis yang dilakukan dalam penelitian ini menggunakan analisis deskriptif kuantitatif. Untuk data kuantitatif dianalisis dengan mencari mean, median, modus, membuat interval kelas dan melakukan penyajian dalam bentuk tabel dan grafik. Penelitian tindakan kelas ini menggunakan tes prestasi belajar sebagai instrumen. Indikator keberhasilan dalam penelitian ini adalah apabila pada akhir siklus II rata-rata nilai siswa mencapai 76 atau lebih dengan ketuntasan belajar minimal 80\%.

\section{Hasil dan Pembahasan}

Penelitian ini dilakukan berdasarkan pada tahap-tahap penelitian kelas yang telah dirumuskan. Adapun tahapan tersebut terdiri dari perencanaan, tindakan, pengamatan dan refleksi. Dalam menyampaikan hasil penelitian dan pembahasan, perlu menyajikan uraian masing-masing siklus dengan data lengkap mulai dari perencanaan, pelaksanaan, pengamatan/observasi dan refleksi yang berisi penjelasan tentang aspek keberhasilan dan kelemahan yang terjadi. Perlu ditambahkan hal yang mendasar, yaitu hasil perencanaan (kemajuan) pada diri siswa, lingkungan, guru, motivasi dan aktivitas belajar. Kemukakan grafik dan tabel hasil analisis data yang menunjukkan perubahan yang terjadi disertai 
pembahasan secara sistematis dan jelas (Suharsimi Arikunto, Suhardjono, Supardi, 2006). Data dalam penelitian ini diperoleh dengan menggunakan instrumen tes prestasi belajar setelah data diperoleh, dilanjutkan dengan pemaparan hasil penelitian yang dimulai dengan deskripsi awal, perencanaan, pelaksanaan, hasil observasi dan refleksi.

Kondisi Pra-Siklus

Deskripsi yang dapat disampaikan untuk perolehan data awal adalah: tidak ada siswa di kelas VIII A5 semester genap tahun pelajaran 2017/2018 memperoleh nilai rata-rata KKM (76). Ada 2 orang yang nilainya sudah diatas KKM dan 22 orang siswa yang nilainya di bawah KKM atau 92,31\%. Data ini menunjukkan bahwa prestasi belajar siswa pada awalnya belum sesuai harapan. Bagi siswa yang masih belum mencapai nilai ketuntasan belajar yang diharapkan diupayakan dapat meningkatkan prestasi belajar mereka untuk tidak terus-menerus merasa asing dengan situasi kelas maupun situasi proses pembelajaran yang dilakukan. Siswa-siswa tersebut tidak mudah untuk diubah, sehingga masih memerlukan perbaikan yang lebih serius.

Pembelajaran pada Siklus I

1) Rencana Tindakan Siklus I

Perencanaan tindakan Siklus I adalah sebagai berikut:

1) Menyusun rencana pelaksanaan pembelajaran (RPP).

2) Berkonsultasi dengan teman-teman guru menyiapkan alat-alat peraga dan bahan-bahan pendukung lainnya.

3) Menyiapkan pedoman penilaian.

4) Merancang skenario pembelajaran dengan menempatkan siswa pada posisi sentral.

5) Menyiapkan media yang akan digunakan dalam proses pembelajaran.

2) Pelaksanaan Tindakan Siklus I

1) Pada saat mulai masuk kelas, guru memberi salam kepada anak.

2) Sebelum KBM guru melakukan apersepsi untuk menumbuhkan rasa percaya diri anak.

3) Menciptakan suasana belajar agar peserta didik dapat belajar dengan nyaman.

4) Menyampaikan materi dengan memberi contoh-contoh yang benar sambil mengajukan pertanyaan-pertanyaan untuk menarik perhatian anak.

5) Mengawasi, memonitoring dan bertindak sebagai fasilitator selama proses pembelajaran

3) Observasi dan Evalusi Siklus I

Observasi dilakukan dengan cara:

1) Menilai tugas-tugas yang disuruh.

2) Mengobservasi kegiatan yang dilakukan peserta didik.

3) Menilai unjuk kemampuan.

4) Memberikan tes.

Hasil yang diperoleh dari tes prestasi belajar dapat dijelaskan sebagai berikut: dari 26 orang siswa yang diteliti sudah 17 orang. (65,38\%) yang memperoleh penilaian di atas KKM, sedangkan 9 orang $(34,62 \%)$ masih di bawah KKM.

4) Refleksi Siklus I

Hasil observasi yang diperoleh selama tindakan I kemudian evaluasi guna menyempurnakan tindakan selanjutnya. Semua dilakukan untuk dapat menunjukkan tingkat kemajuan-kemajuan yang dicapai, mencari kekurangan-kekurangan yang ada selama proses pelaksanaan tindakan, untuk dijadikan acuan perbaikan.

Refleksi dalam penelitian menurut para ahli menyangkut kegiatan analisis, sintesis, dan penilaian terhadap hasil pengamatan atas tindakan yang dilakukan (Hopkin, 1993 dalam Suharsimi Arikunto, Suhardjono, Supardi, 2006). Analisis refleksi pada siklus I dapat disajikan dalam data kelas interval pada Tabel 1.

Tabel 1. Data Kelas Interval Pembelajaran Siklus I

\begin{tabular}{ccccc}
\hline No Urut & Interval & Nilai Tengah & Frekuensi Absolut & Frekuensi Relatif \\
\hline 1 & $75-77$ & 76 & 9 & 34.62 \\
2 & $78-80$ & 79 & 14 & 53.85 \\
3 & $81-83$ & 82 & 0 & - \\
4 & $84-86$ & 85 & 2 & 7.69 \\
5 & $87-89$ & 88 & 0 & - \\
6 & $90-92$ & 91 & 1 & 3.85 \\
\multicolumn{2}{c}{ Jumlah } & & 26 & 100 \\
\hline
\end{tabular}


Berdasarkan Tabel 1 menunjukkan bahwa prestasi belajar siswa pada siklus I adalah dari 26 orang siswa yang diteliti masih ada kekurangan yaitu baru 17 orang yang sudah mampu menyerap ilmu tetapi masih 9 orang yang belum berhasil. Data yang diperoleh tersebut dapat mendeskripsikan indikator yang diharapkan belum tercapai.

Hasil penilaian terhadap seluruh kegiatan penelitian yang sudah dilakukan pada Siklus I perlu dijelaskan semua kekurangan-kekurangan yang ada.

Kekurangan-kekurangan yang ada, yaitu, pertama, siswa masih membutuhkan waktu yang lebih lama untuk terbiasa menyelesaikan kegiatannya menggunakan model pembelajaran yang baru, dan yang kedua, sarana kurang memadai sehingga pembelajaran belum dapat dilaksanakan secara maksimal. Semua kekurangan yang telah disampaikan itu akan dibenahi selanjutnya pada pembelajaran siklus II.

Pembelajaran pada Siklus II

1) Rencana Tindakan Siklus II

Rencana yang dilaksanakan pada siklus II sama dengan rencana tindakan siklus I. Perbaikan yang dilakukan diantaranya:

1) Lebih banyak membuat variasi kegiatan agar semua siswa mendapat bagian untuk dikerjakan.

2) Merencanakan langkah-langkah yang harus diikuti secara perlahan-lahan menuju yang lebih sulit.

3) Mengupayakan tutor teman sejawat.

4) Anak yang berhasil giat diberikan pujian dan penghargaan.

2) Pelaksanaan Tindakan Siklus II

Pelaksanaan tindakan pada siklus II sama dengan siklus I sebanyak 3 kali pelaksanaan tindakan dengan beberapa fokus perbaikan yang harus dikerjakan. Fokus perbaikan yang telah ditetapkan untuk dilaksanakan seperti tercantum pada RPP dengan giat dalam penerapannya sehingga bisa diharapkan mampu memperbaiki beberapa kelemahan yang terjadi pada siklus sebelumnya. Peneliti berusaha menciptakan suasana pembelajaran yang lebih menarik dan kondusif sehingga siswa lebih antusias mengikuti kegiatan pembelajaran. Peneliti berusaha menciptakan suasana supaya siswa mampu menghargai kemampuannya sendiri serta menggunakan metode yang bervariasi.

3) Observasi dan Evalusi Siklus II

Untuk mengetahui sejauh mana tingkat perkembangan mereka, guru menggunakan pengamatan lewat tes prestasi belajar. Data yang diperoleh dari hasil penilaian tes prestasi belajar dapat dijelaskan bahwa dari 26 orang siswa, 24 siswa (92,30\%) memperoleh nilai rata-rata di atas KKM dan 2 orang $(7,69 \%)$ masih di bawah rata-rata. Gambaran yang dapat disampaikan adalah mereka sangat berkembang yang artinya bahwa mereka mampu menyelesaikan tugas dengan baik. Hasil observasi pada siklus II ini ternyata sudah menunjukkan keberhasilan sesuai tuntutan indikator keberhasilan penelitian.

4) Refleksi Siklus II

Peningkatan prestasi belajar siwa pada Siklus II ini adalah dari 26 siswa yang diteliti ternyata hasilnya sudah sesuai dengan harapan. Dari perkembangan tersebut diketahui semua siswa mampu menyelesaikan kegiatan yang disuruh dengan baik, mereka sudah belajar giat, peneliti juga sudah berupaya keras agar siswa mampu mencapai hasil sesuai harapan. Dari semua data yang diperoleh tersebut dapat diberikan sintesis bahwa seluruh siswa sudah mampu meningkatkan prestasi belajar mereka, hal tersebut berarti semua indikator yang diharapkan dicapai oleh siswa SMP Negeri 3 Sawan sudah terpenuhi. Penilaian yang dapat diberikan terhadap pelaksanaan Siklus II ini yaitu pembelajaran menggunakan model pembelajaran Creative Problem Solving telah tuntas dapat dilaksanakan. Semua kekurangan-kekurangan yang ada sudah diperbaiki pada siklus ini, sehingga tidak ada yang masih perlu dipaksakan oleh peneliti bahwa penelitian ini tidak perlu dilanjutkan lagi ke siklus berikutnya. Analisis refleksi pada siklus II dapat disajikan dalam data kelas interval pada Tabel 2.

Tabel 2. Data Kelas Interval Pembelajaran Siklus II

\begin{tabular}{ccccc}
\hline $\begin{array}{c}\text { No } \\
\text { Urut }\end{array}$ & Interval & Nilai Tengah & Frekuensi Absolut & Frekuensi Relatif \\
\hline 1 & $75-77$ & 76 & 2 & 7.69 \\
2 & $78-80$ & 79 & 7 & 26.92 \\
3 & $81-83$ & 82 & 0 & - \\
4 & $84-86$ & 85 & 14 & 53.85 \\
5 & $87-89$ & 88 & 0 & - \\
\hline
\end{tabular}




\begin{tabular}{ccccc}
\hline 6 & $90-92$ & 91 & 2 & 7.69 \\
& & 26 & 100 \\
\hline
\end{tabular}

Penilaian terhadap seluruh kegiatan penelitian yang sudah dilakukan pada Siklus II perlu dijelaskan bahwa pada Siklus II ini semua indikator yang dituntut dalam pembelajaran telah secara tuntas dapat dilaksanakan. Semua kekurangan-kekurangan yang ada pada siklus sebelumnya sudah diperbaiki pada siklus ini, sehingga tidak ada yang masih perlu diragukan bahwa indikator yang dituntut untuk diselesaikan tidak ada lagi yang tertinggal. Semua hasil yang diperoleh pada Siklus II ini menunjukkan bahwa penelitian ini tidak perlu dilanjutkan lagi ke siklus berikutnya karena keberhasilan yang dituntut agar peserta didik mencapai ketuntasan belajar minimal $80 \%$ sudah terpenuhi dengan hasil yang diperoleh sudah tercapai 92,31\%.

Penggunaan model pembelajaran Inquiry dalam pembelajaran Matematika ternyata sangat membantu siswa untuk lebih aktif dalam pembelajaran dan peran guru sebagai fasilitator terlaksana dengan sangat baik. Selain itu, suasana pembelajaran lebih fokus pada pengulangan dan penguasaan materi dengan bantuan teman sehingga tujuan pembelajaran dapat tercapai. Model pembelajaran ini menunjukkan hasil bahwa intensitas siswa untuk melakukan gerakan bertambah, munculnya motivasi kerjasama antar teman, kreativitas siswa tersalurkan, guru dan siswa sama-sama aktif dan kreatif, belajar lebih bermakna karena proses pembelajaran dapat lebih menyenangkan.

Menurut Arifin (2012) prestasi adalah hasil dari kemampuan, keterampilan dan sikap seseorang dalam menyelesaikan suatu hal. Prestasi adalah hasil yang telah dicapai (dari yang telah dilakukan, dikerjakan, dan sebagainya. Prestasi belajar adalah penguasaan pengetahuan atau keterampilan yang dikembangkan melalui mata pelajaran, lazimnya ditunjukkan dengan nilai tes atau angka nilai yang diberikan guru (Depdiknas, 2005). Adapun Suryabrata (2002), menyatakan bahwa nilai raport merupakan perumusan terakhir yang diberikan guru mengenai kemajuan prestasi belajar siswa selama masa tertentu. Prestasi dalam belajar merupakan dambaan bagi setiap orangtua terhadap anaknya. Prestasi yang baik tentu akan didapat dengan proses belajar yang baik juga.

Menurut Sumadi Suryabrata (2006), prestasi dapat pula didefinisikan sebagai berikut: "nilai merupakan perumusan terakhir yang dapat diberikan oleh guru mengenai kemajuan/prestasi belajar siswa selama masa tertentu". Jadi, prestasi adalah hasil usaha siswa selama masa tertentu melakukan kegiatan.

Sedangkan menurut Kamus Besar Bahasa Indonesia (2005) prestasi adalah hasil yang telah dicapai (dari yang telah dilakukan, dikerjakan dan sebagainya). Prestasi merupakan hasil suatu usaha yang telah dilaksanakan menurut batas kemampuan dari pelaksanaan usaha tersebut. Sedangkan Sutratinah Tirtonegoro (2001) menyatakan bahwa prestasi belajar adalah penilaian hasil usaha kegiatan belajar mengajar yang dalam bentuk simbol, angka, huruf, atau kalimat yang dapat mencerminkan hasil usaha yang sudah dicapai oleh anak dalam periode tertentu.

Belajar merupakan perubahan tingkah laku atau penampilan, dengan serangkaian kegiatan misalnya dengan membaca, mengamati, mendengarkan, meniru dan sebagainya. Belajar juga akan lebih baik, kalau subyek belajar itu mengalami atau melakukannya, jadi tidak bersifat verbalistik. Disamping difinisi tersebut, ada beberapa pengertian lain yang cukup banyak, baik dilihat secara mikro maupun secara makro, dilihat dalam arti luas atau pun terbatas. Dalam pengertian luas, belajar dapat diartikan sebagai kegiatan psiko-fisik menuju perkembangan pribadi seutuhnya, kemudian dalam arti sempit, belajar dimaksudkan sebagai usaha penguasaan materi ilmu pengetahuan yang merupakan sebagian kegiatan menuju terbentuknya kepribadian seutuhnya. Relevan dengan ini maka ada pengertian bahwa belajar adalah penambahan pengetahauan (Sardiman, 2009).

Bruner (dalam Nasution, 2006) menganggap bahwa belajar dan persepsi merupakan suatu kegiatan pengolahan informasi yang menemukan kebutuhan-kebutuhan untuk mengenal dan menjelaskan gejala yang ada dilingkungan kita.Prestasi belajar tidak dapat dipisahkan dari perbuatan belajar, karena belajar merupakan suatu proses, sedangkan prestasi belajar adalah hasil dari proses pembelajaran tersebut. Bagi seorang siswa belajar merupakan suatu kewajiban. Berhasil atau tidaknya seorang siswa dalam pendidikan tergantung pada proses belajar yang dialami oleh siswa tersebut.

Menurut Sardiman (2011), belajar akan lebih baik apabila subyek belajar mengalami atau melakukannya, belajar dapat diartikan sebagai kegiatan psikofisik menuju keperkembangan pribadi seutuhnya. Belajar juga dapat diartikan sebagai usaha penguasaan materi ilmu pengetahuan yang sebagian bertujuan untuk membentuk kepribadian seutuhnya. Menurut Sugihartono (2007), merupakan suatu proses memperoleh pengetahuan dan pengalaman dalam wujud perubahan tingkah laku dan kemampuan bereaksi yang relatif permanen atau menetap karena adanya interaksi individu dalam lingkungannya. 
Pada hakekatnya belajar adalah suatu proses yang ditandai dengan adanya perubahan pada diri seseorang. Perubahan sebagai hasil proses belajar dapat ditunjukkan dengan berbagai bentuk seperti berubahnya pengetahuan, pemahaman, sikap dan tingkah lakunya, keterampilan, kecakapan dan kemampuannya, dan aspek-aspek lain yang ada pada individu tersebut. Apa yang dikemukakan tersebut didukung oleh beberapa definisi belajar oleh para ahli.Menurut Sardiman A.M belajar sebagai rangkaian kegiatan jiwa-raga, psiko-fisik menuju ke perkembangan pribadi manusia seutuhnya, yang menyangkut unsur cipta, rasa dan karsa, ranah kognitif, afektif dan psikomotorik.

Hasil tes prestasi belajar di siklus I telah menemukan efek utama bahwa pelaksanaan tindakan berpengaruh terhadap prestasi belajar anak. Hal ini sesuai dengan hasil meta analisis metode pembelajaran yang dilakukan oleh Soedomo (dalam Puger, 2004) yang menyatakan bahwa metode pembelajaran yang diterapkan oleh seorang guru berpengaruh terhadap prestasi belajarnya.

Permasalahan yang masih tersisa yang perlu dipecahkan adalah prestasi belajar yang dicapai pada siklus I ini belum memenuhi harapan sesuai dengan tuntutan indikator keberhasilan penelitian yakni $80 \%$ atau lebih ketercapaian untuk ketuntasan secara klasikal. Nilai rata-rata siswa yang diperoleh 79,04. Oleh karenanya upaya perbaikan lebih lanjut masih perlu diupayakan sehingga penelitian masih harus berlanjut ke siklus berikutnya.

Data yang diperoleh peneliti dari hasil tes prestasi belajar di siklus II menunjukkan bahwa kemampuan siswa dalam mengikuti pelajaran sudah sangat baik. Ini terbukti dari rata-rata nilai siswa mencapai 83,65. Hasil ini menunjukkan bahwa pelaksanaan tindakan telah berhasil meningkatkan kemampuan anak menempa ilmu sesuai harapan.

Efek pembuktian tentang kebenaran tindakan yang dilaksanakan telah berhasil ditunjukkan bahwa tindakan yang diterapkan dalam proses pembelajaran berpengaruh secara signifikan terhadap prestasi belajar siswa. Model pembelajaran Inquiry merupakan suatu model pembelajaran yang dilakukan dengan cara memperdayakan kemampuan siswa yang memiliki daya serap yang tinggi. Siswa mampu membelajarkan dirinya sehingga memiliki daya serap yang tinggi. Pembelajaran ini mempunyai kelebihan ganda yaitu siswa yang mendapat bantuan lebih efektif dalam menerima materi sedangkan bagi temanteman yang lain merupakan kesempatan untuk mengembangkan kemampuan diri. Dampak positifnya adalah meningkatkan usaha kognitif, komunikasi, percaya diri, dan mendukung hubungan sosial diantara siswa sehingga prestasi belajar siswa dapat tercapai.Dengan model ini keaktifan positif dalam proses belajar mengajar dan menghasilkan hasil belajar yang lebih baik.

Proses yang dilakukan dalam pembelajaran dengan model pembelajaran Inquiry lebih mengkaji aspek kognitif, afektif dan psikomotor sebagai pedoman atas kemampuan anak baik pikiran, prilaku maupun keterampilan yang dimiliki. Perbandingan nilai awal, nilai siklus I dan nilai siklus II, menunjukkan terjadinya kenaikan prestasi yang signifikan, yaitu dari rata-rata nilai awal adalah 69,23 naik di siklus I menjadi 79,04 dan di siklus II naik menjadi 83,65. Kenaikan ini menunjukkan upaya maksimal yang dilaksanakan peneliti demi peningkatan kualitas pembelajaran dan mutu pendidikan pendidikan khususnya di SMP Negeri 3 Sawan.

\section{Simpulan dan Saran}

Berdasarkan hasil penelitian dan pembahasan yang telah diuraikan, dapat disimpulkan bahwa aplikasi model pembelajaran inquiri dapat meningkatkan prestasi belajar bagi siswa kelas VIII A5 SMP Negeri 3 Sawan Semester Genap Tahun Pelajaran 2017/2018. Hal ini dapat dilihat dari semakin meningkatnya prestasi belajar matematika. Pada refleksi awal rata-rata nilai matematika siswa sebesar 69,23 dengan ketuntasan 7,69 \% dan pada siklus I nilai rata-rata siswa meningkat menjadi 79,04 dengan ketuntasan 65,38\% walaupun masih dalam kategori cukup tapi sudah ada peningkatan pada nilai ratarata siswa sebesar 9,81\%. Setelah dilaksanakan perbaikan tindakan pada siklus II, rata-rata nilai matematika siswa pada siklus II sebesar 83,65 mengalami peningkatan sebesar 4,61\% dari Siklus I dan berada pada kategori baik dan 92,31\% siswa tuntas.

Keberhasilan tindakan yang dilakukan dalam penelitian seperti yang telah diuraikan sebelumnya telah memberikan hasil yang optimal bagi siswa, berdasarkan acuan tersebut, maka disarankan dalam melaksanakan proses pembelajaran agar hasil belajar siswa dapat dicapai secara optimal disarankan agar guru-guru membuat persiapan yang matang dan mampu menentukan atau memilih topik yang benarbenar bisa diterapkan dengan model pembelajaran Inquiry agar diperoleh hasil yang optimal. Disisi lain, disarankan juga bagi guru yang ingin meningkatkan prestasi belajar siswa, hendaknya lebih sering melatih siswa dengan kegiatan pengolahan keterampilan berpikir kritis melalui penemuan walau dalam taraf yang sederhana, di mana siswa nantinya dapat menemukan pengetahuan baru, memperoleh konsep dan keterampilan, sehingga siswa berhasil atau mampu memecahkan masalah-masalah yang dihadapinya. 


\section{Daftar Rujukan}

Arifin, Zainal. 2012. Evaluasi Pembelajaran. Bandung: PT. Remaja Rosdakarya.

Arikunto, S., Suhardjono dan Supardi. 2006. Penelitian Tindakan Kelas. Jakarta: PT Bumi Aksara.

Depdiknas. 2005. Kamus Besar Bahasa Indonesia. Jakarta : Balai Pustaka.

Febriyani, 2014. "Penerapan Model Pembelajaran Inkuiri untuk meningkatkan hasil belajar IPA siswa kelas V SD No. 4 Selat Kecamatan Sukasada Tahun Pelajaran 2013/2014". Jurnal Mimbar PGSD Vol 1 No 1.

Juniati, Ni Wayan dan I Wayan Widiana. (2017). Penerapan Model Pembelajaran Inkuiri Untuk Meningkatkan Hasil Belajar IPA. Jurnal Ilmiah Sekolah Dasar. Vol.1 (1) pp. 20-29.

Jus Pariatna, I Wayan \& Ida Bagus Nyoman Sudria, Ngadiran Karto Wasono. 2015. "Pengembangan Perangkat Pembelajaran Inkuiri Terbimbing pada Topik Laju Reaksi". Jurnal Wahana Matematika Dan Sains, Volume 9, Nomor 1, April 201538.

Maksum, A. 2006. Pengaruh Metode Pembelajaran Inquiri terhadap Hasil Belajar Sejarah dan Sikap Nasionalisme Siswa Kelas XI SMA Negeri1 Sukamulia, Lombok Timur, NTB. Tesis. Universitas Pendidikan Ganesha. Program Pascasarjana. Singaraja.

Marheni, Ni Putu \& I Nyoman Suardana. "Pembelajaran Inkuiri Terbimbing Berbasis Budaya Lokal pada Pembelajaran Sains Kimia SMP". Jurnal Wahana Matematika dan Sains, Volume 8 Nomor 2, Oktober 2014 (87)

Mariati. Y. 2014. Pengaruh Model Inkuiri Terbimbing Berbasis Lingkungan terhadap Keterampilan Kreatif dan Penguasaan Konsep IPA Kelas V SD e-Journal STKIP NU Indramayu, Jawa Barat 6 (12). 1-5. Tersedia pada http://www.stkippnuiac.id. Diakses pada 23 April 2017

Metaputri, Ni Kadek dan Ni Nym. Garminah. 2016. "Pengaruh Model Pembelajaran Inkuiri Terbimbing dan Minat Belajar terhadap Keterampilan Proses Sains pada Siswa Kelas IV SD”. Jurnal Pendidikan dan Pengajaran, Jilid 49, Nomor 2, Juli 2016, hlm. 89-97

Modern Educators and Lexicographers. 1939. Webster's New American Detionary. New York: 140 Broadway, Books, Inc.

Nasution. S. 2006. Berbagai Pendekatan Dalam Proses Belajar Mengajar. Jakarta : Rineka Cipta.

Poerwadarminta, W.J.S. 2003. Kamus Umum Bahasa Indonesia. Jakarta: Balai Pustaka.

Putrayasa, I. B. 2005. Pembelajaran Bahasa Indonesia Berbasis Inquiri dalam Upaya Meningkatkan Aktivitas, Kreativitas, dan Logikalitas. Tesis. Institut Keguruan dan Ilmu Pendidikan Negeri Singaraja.

Sardiman, A.M. 2011. Interaksi dan Motivasi Belajar Mengajar. Jakarta: PT. Raja Grafindo Persada.

Sugihartono. 2007. Psikologi Pendidikan. Yogyakarta: UNY Press.

Sukidin, B. dan Suranto. 2002. Menajemen Penelitian Tindakan Kelas. Jakarta: Insan Cendekia.

Sumarti.S.,Rahayu.S.,Madlazim.2015. “Pembelajaran IPA dengan Inkuiri Terbimbing Menggunakan Hypermedia dan Media Riil Ditinjau gaya Belajar dan Kemampuan Awal". Jurnal Pendidikan \& Pembelajaran. 2 (2). 45-52. Tersedia pada http://www.unes.ac.id. Diakses 8 April 2017.

Suryabrata, S. 2002. Psikologi Pendidikan. Jakarta : PT. Raja Grafindo Persada. 
Suryabrata, S. 2006. Psikologi Kepribadian. Jakarta: Raja Grafindo Persada.

Suryaningsih, Ni Made Ayu \& I Made Elia Cahaya, Christiani Endah Poerwati. 2016. "Implementasi Pembelajaran Inkuiri Terbimbing Berbasis Permainan dalam Meningkatkan Kreativitas Anak Usia Dini”. Jurnal Pendidikan Indonesia Vol. 5, No. 2, Oktober 2016 (212-220).

Tirtonegoro, S. 2001. Penelitian Hasil Belajar Mengajar. Surabaya: Usaha Nasional. 